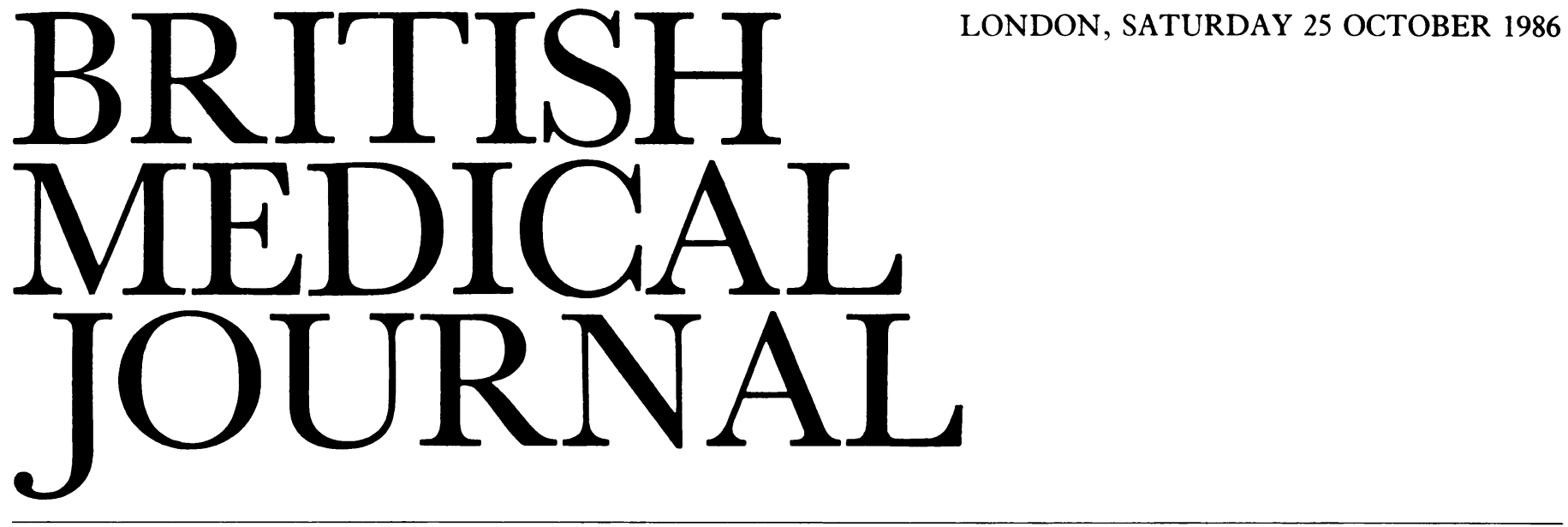

\title{
Viral warts: a new look at an old problem
}

The infectious nature of warts was discovered at the end of the last century ${ }^{1}$ and the cause, the human papilloma virus, identified in $1950,{ }^{2}$ but only in the past two decades have real advances been made in understanding wart behaviour. First came information on their immunology, and more recently new virological techniques applied to the DNA of human papilloma virus have shown the plurality of the viruses ${ }^{3+}$; each is associated with clinically distinctive warts, and some seem carcinogenic. ${ }^{5}$ The virus has still not, however, been cultured.

Several types of warts occur on the skin: deep painful palmoplantar warts or myrmecia (HPV1), common warts (HPV2), mosaic warts (HPV2), plane warts (HPV3), and punctate palmoplantar warts (HPV4). They occur in both male and female genital tracts (HPV6, 11, 16, 18) and rarely in the larynx of children whose mothers had genital warts at delivery. Warts related to the human papilloma viruses found in skin and genital warts also occur in the mouth. The rare lifelong disease epidermodysplasia verruciformis is characterised by a multiplicity of warts carrying many virus types, 14 of which are found only in this condition. ${ }^{6}$

Infection with human papilloma virus occurs when infected squames either from another part of the body or from another person enter through breaches in the skin and mucosa. Fresh infected scales deposited on warm moist floors or towels may also be a source, although human papilloma virus does not seem to survive for long under these circumstances. ${ }^{7}$ Recently it has been shown that the virus can lie dormant in apparently normal skin and mucosa. ${ }^{89}$

In common with most other viral infections human papilloma virus infection may regress spontaneously and completely. Circulating antibodies and evidence of a cell mediated immune response are both seen when warts are cured either spontaneously or through treatment, ${ }^{10}$ but the cell mediated immune response is thought to be principally responsible. ${ }^{11 \cdot 13}$ Analysis of the cells infiltrating the epidermis and upper dermis of regressing warts shows a cell mediated immune response against keratinocytes infected with human papilloma virus. ${ }^{1+}$ The role of circulating antibodies is still not clear, ${ }^{x}$ but the warts may regress in different ways-silent shrinkage, swelling and inflammation, or haemorrhagic necrosis.'

Spontaneous regression may start between three months and five years after the appearance of the warts and is complete in three to four weeks. ${ }^{16}$ The onset of spontaneous regression and the response of warts to treatment varies greatly and is influenced not only by the type and amount of human papilloma virus present but also by the patient's immunological state. Those with a primary deficiency in cell mediated immunity suffer from widespread and resistant warts, ${ }^{17}$ and others with immunological derangements-such as autoimmune diseases, atopy, and sarcoidosis-also have problems. ${ }^{1819}$ The worst affected group are those taking immunosuppressive drugs, in particular allograft recipients -for them warts may become a serious disability. ${ }^{20}$

Advances in treating warts have not been spectacular, and none of the new antiviral drugs has proved effective against human papilloma virus. Assessment of the wide range of available treatments is made difficult by the variability of response and the unpredictability of spontaneous resolution, so a stringent protocol is essential. ${ }^{21}$ While $20 \%$ of normal individuals will lose their warts spontaneously within three months, the self application of salicylic acid wart paints if used correctly will cure $70-80 \%$ of common warts and 80 $90 \%$ of deep plantar warts within that time, ${ }^{21}$ and this is therefore the treatment of choice in most cases. Cryotherapy has gained great popularity, but the cure rate differs little from that associated with salicylic acid paints. ${ }^{21}$ Freezing is painful, and more than one treatment is usually required. There is a place for curettage or electrocautery, or both, under special circumstances but never for surgical excision because it leaves unnecessary scars. Lasers do not offer a certain cure.

Treating patients with resistant warts is more difficult. Plane warts, a cosmetic problem, will resolve after a few years and are best left alone. Mosaic warts require persistent treatment over many months with a rotation of topical applications, with or without cryotherapy, or by one of the newer methods discussed below.

Anogenital warts (condyloma acuminata) have traditionally been treated with podophyllin, but this is very toxic if much is absorbed and is teratogenic. ${ }^{2223}$ It may cause violent local reactions if left on too long, and self application is best avoided. Freezing anogenital warts with a liquid nitrogen spray is a good alternative and not unduly painful-and may be safely used during pregnancy.:- Curettage, cautery, destruction by carbon dioxide laser, and removal by Thomson's scissor snip technique ${ }^{25}$ are all alternatives. Fluorouracil cream is sometimes successful with widespread vaginal and cervical warts. ${ }^{26}$ Recurrences of genital warts, 
however treated, are common and understandable as human papilloma virus persists in apparently normal tissue. ${ }^{10}$ Reinfection by the sexual partner may also be a factor, and consorts should be checked and treated simultaneously whenever possible.

Early treatment of warts in immunoincompetent patients is essential, and destructive procedures-such as cryotherapy, curettage, cautery, or one of the new intralesional methods-are successful if used before the infection becomes widespread.

There are new approaches for treating resistant warts. Retinoids will reduce the hyperkeratosis appreciably, ${ }^{19}$ but infection is not eradicated and the warts return when the drug is stopped. Immunostimulation is the aim of several methods. Levamisole did not live up to its early promise. ${ }^{27}$ Inosine is now being assessed. Dinitrochlorobenzene sensitisation and challenge has been used successfully, ${ }^{28}$ but patients cannot always be sensitised and serious side effects are common-this method has thus become less popular. ${ }^{29}$ Patients can no longer be treated with autogenous vaccines because of the possible oncogenic effect of the viral DNA, but the development of a human papilloma virus subunit vaccine through direct isolation of the surface antigen gene from the genome is being explored. ${ }^{30}$ The success of vaccines is not, however, ensured, and the Lyons group failed to cure all their patients using formalin treated purified human papilloma virus virons. ${ }^{3}$

Interferon eradicates in vitro cells infected with papilloma virus $^{32}$ and has mostly been used to treat genital warts. Both $\alpha$ and $\beta$ forms have been used, either systemically or given into the wart with some encouraging results, ${ }^{33}{ }^{34}$ and a vaginal cream is shortly to be introduced. Although interferon may destroy infectivity, there is some disturbing evidence that human papilloma virus DNA itself is not eradicated, and rapid and florid recurrences and even malignancy have followed cessation of treatment in some HPV16 infections. ${ }^{35}$ Systemic interferon will cause regression of widespread warts in allograft recipients, but it is difficult to achieve an adequate dose without dangerous depression of an already low neutrophil count. The intralesional route has sometimes succeeded when the systemic has failed. ${ }^{36}$ Intralesional injection of longstanding resistant mosaic warts with interferon in an open study has shown some dramatic results, ${ }^{37}$ but the multiple frequent injections required are daunting. Patients still experience the flu like symptoms associated with systemic interferon, but there appears to be less white cell suppression. Further experience with adjusted regimens for giving interferon may well be fruitful.

Bleomycin sulphate solution injected in very small doses into resistant warts has proved highly successful. ${ }^{38} 39$ No systemic side effects have been experienced, nor would they be expected with the doses used. The pain associated with the haemorrhagic necrosis of the wart is tolerated by the informed patient with the aid of an analgesic, and careful injections leave no scarring. One or two isolated cases of local complications have been reported ${ }^{40}{ }^{41}$ but are not generally experienced. This is a simple, safe, and usually successful treatment, but, strangely, only in Canada has the drug been licensed for treating warts.

No article on warts is complete without mentioning the relation between warts and cancer. Although certain types of human papilloma virus are implicated in carcinogenesis, they are not the types commonly found in skin warts (HPV1-4). HPV5 DNA was the first to be shown in the skin cancers that occur in about a third of patients with epidermodysplasia verruciformis, ${ }^{42}$ and subsequently it was found in a patient who had had a renal allograft. ${ }^{43}$ There is great concern about how often HPV16 and 18 DNA is being found in malignant lesions of both the male and female genitalia, including the cervix, ${ }^{44}$ but the exact role of these viruses in carcinogenesis remains to be elucidated. Whether they are initiators or activators, many other factors are important, ${ }^{45}$ and not every individual carrying these potentially carcinogenic viruses will develop cancer. Nevertheless, they must be identified. At present human papilloma virus typing is too complicated to be a routine laboratory service. New simpler techniques are, however, being developed and may soon make routine typing possible. ${ }^{46} 47$

Research Fellow,

MARY H BUNNEY

University Department of Dermatology,

Royal Infirmary,

Edinburgh EH3 9RW

1 Payne J. On the contagious rise of common warts. Br f Dermatol 1891;52:43.

2 Strauss MJ, Bunting MD, Melnick JL. Virus-like particles and inclusion bodies in skin papillomas. F Invest Dermatol 1950;15:433.

issman L, Pfister $\mathrm{H}$, zur Hausen $\mathrm{H}$. Human papilloma viruses (HPV): characterization of four different isolates. Virology 1977;76:569-80.

4 Orth G, Favre $M$, Croissant $\mathrm{O}$. Characterization of a new type of human papilloma virus that causes skin warts. $\mathcal{F}$ Virol $1977 ; 24: 108-20$

5 zur Hausen H, Gissman L. Papilloma viruses. In: Klein G, ed. Viral oncology. New York: Raven Press, 1980:433-5.

6 Orth G, Favre M. Human papilloma viruses, biochemical and biologic properties. Clinics in Dermatology 1985;3/5:27-42.

7 Gentles JC, Evans EGV. Foot infections in swimming baths. Br Med f 1973;iii:685.

8 Bender ME. Concepts of wart regression. Arch Dermatol 1986;122:644-7.

9 Cox MF, Meanwell CA, Maitland NJ, Blackledge G, Scully C, Jordan JA. Human papilloma virus type-16 homologous DNA in normal human ectocervix. Lancet 1986;ii:157-8.

10 Matthews RS, Shirodaria PV. Study of regressing warts by immunofluorescence. Lancet 1973;i:689-91.

11 Berman A, Winkelman RK. Involuting common warts. F Am Acad Dermatol 1980;3:356-62.

2 Tagami H, Ogino A, Takigawa M, Imamura S, Ofuji S. Regression of plane warts following spontaneous inflammation. A histopathological study. Br $\mathcal{F}$ Dermatol 1974;90:147-54.

13 Viac J, Thivolet J, Hegazy MR, Chardonnet Y, Dambuyart C. Comparative study of delayed hypersensitivity reactions and antibodies to HPV. Clin Exp Immunol 1977;29:240-6.

14 Iwatsuki K, Tagami H, Takigawa M, Yamada M. Plane warts under spontaneous regression. Arch Dermatol 1986;122:655-9.

15 Bunney MH. Viral warts: their biology and treatment. Oxford: Oxford University Press, 1982:22-5. 16 Massing AM, Epstein WL. Natural history of warts. Arch Dermatol 1963;87:306.

7 Lutzner MA. Papilloma virus lesions in immunodepression and immunosuppression. Clinics in Dermatology 1985;3/5:165-9.

18 Johansson EA. Warts and wart virus antibodies in patients with systemic lupus erythematosus. In Prunieras $M$, ed. Biomedical aspects of human wart infection. Lyons: Fondation Merieux, 1975:259-61.

19 Boyle J, Dick DC, MacKie RM. Treatment of extensive viral warts with etretinate (Tigason) in patient with sarcoidosis. Clin Exp Dermatol 1983;8:33-6.

20 Spencer ES, Andersen HK. Viral infections in renal allograft recipients treated with longterm immunosuppression. Br Med $\mathcal{F}$ 1979; ii:829-30.

21 Bunney $\mathrm{MH}$, Nolan $\mathrm{M}$, Williams $\mathrm{D}$. An assessment of methods of treating viral warts by comparative treatment trials based on a standard design. Br f Dermatol 1976;94:667-9.

22 Slater GE, Rumack BH, Peterson RG. Podophyllin poisoning. Systemic toxicity following cutaneous application. Obstet Gynecol 1978;52:94-6.

23 Chamberlain MJ, Reynolds AL, Yeoman WB. Toxic effect of podophyllum application in pregnancy. BrMed F 1972;iii:391-2.

24 Bergman A, Bhatia NN, Broen EM. Cryotherapy for treatment of genital condylomata during pregnancy. I Reprod Med 1984;29:432-5.

25 Thomson JPS. Perianal and anal condyloma acuminata. In: Smith R, Robb C, eds. Operative surgery. 3rd ed. London: Butterworth, 1977:376-7

26 Ferenczy A. Comparison of 5-fluorouracil and $\mathrm{CO}_{2}$ laser for treatment of vaginal condylomata. Canadian Obstetrics and Gynaecology 1984;6:773-8.

27 Schou M, Helin P. Levamisole in a double blind study. No effect on warts. Acta Derm Venereo (Stockh) 1977;57:449-54.

28 Millikan L. Task force on DNCB reports survey results. [Abstract.] $f$ Am Acad Dermato 1982;7:91-2A.

29 Pass F. Newer concepts of wart therapy. In: Report of 39th Annual Meeting American Academy of Dermatology. $f$ Am Acad Dermatol 1981;5:484-99.

30 Faras AJ, Pass F. Applications of biotechnology to human papillomavirus-induced diseases. Clinics in Dermatology 1985;3/4:200-3.

31 Viac J, Thivolet J, Hegazy MR, Chardonnet Y, Dambuyart C. Comparative study of delayed hypersensitivity reactions and antibodies to HPV. Clin Exp Immunol 1977;29:240-6.

32 Turek LP, Byrne JC, Lowy DR, et al. Interferon induces morphologic reversion with elimination of extra-chromosomal viral genomes in bovine papillomavirus-transformed mouse cells. Proc of extra-chromosomal viral genomes in

33 Schonfeld A, Schattner A, Crespi M, et al. Intramuscular human interferon-B injections in treatment of condylomata acuminata. Lancet 1984;i:1038-42.

34 Scott GM, Csonka GW. Effect of injections of small doses of human fibroblast interferon into genital warts. British fournal of Venereal Disease 1979;55:442-5.

35 Gross G, Ikenberg H, Gissmann L. Bowenoid dysplasia in human papillomavirus-16 DNA positive flat condylomas during interferon-B treatment. Lancet 1984;i:1467-8.

36 Pazin GJ, Monto H, Haverkos HW, et al. Effects of interferon-alpha on human warts. $J$ Interferon Res 1982;2:235-43.

37 Gibson JR, Harvey SG, Kemmett D, Salisbury J, Marks P. Treatment of common and plantar viral warts with human lymphoblastoid interferon-alpha- pilot studies with intralesional and dermoject injections. Br $\mathcal{Y}$ Dermatol 1986;115(suppl 31):76-9.

38 Bunney MH, Nolan MW, Buxton PK, et al. The treatment of resistant warts with intralesional bleomycin: a controlled clinical trial. Br f Dermatol 1984;111:197-207.

39 Shumer SM, O'Keefe EJ. Bleomycin in the treatment of recalcitrant warts. $f$ Am Acad Dermatol 1983;9:91-6. 
40 Miller RAW. Nail dystrophy following intralesional injection of bleomycin for a periungual wart. Arch Dermatol 1984;120:963-4.

41 Epstein E. Persisting Raynaud's phenomenon following intralesional bleomycin treatment of finger warts. 3 Am Acad Dermatol 1985; 13:468-71.

42 Jablonska S, Dabrowski J, Jakubowicz K. Epidermo-dysplasia verruciformis as a model in studies on the role of papovavirus in oncogenesis. Cancer Res 1972;32:583-9.

43 Lutzner MA, Orth G, Dutronquay V, et al. Detection of human papillomavirus type 5 DNA in skin cancers of an immunosuppressed renal allograft recipient. Lancet 1983;i:422-4.

44 Singer A, Walker PG, McCance DJ. Genital wart virus infections: nuisance or potentially lethal. BrMed $\mathcal{A}$ 1984;288:735-7.
Bringer

45 Orth G, Favre M. Human papillomaviruses. Biochemical and biologic properties. Clinics in Dermatology 1985;3/4:27-42.

46 Langdale JA, Malcolm ADB. A rapid method of gene detection using DNA bound to sephacryl. Gene 1985;30:201-10.

47 Beckmann AM, Myerson D, Daling JR, Kiviat N, Fenoglio CM, McDougall JK. Detection and localisation of human papillomavirus DNA in human genital condylomas by in situ hybridisation with biotinylated probes. $\mathcal{F}$ Med Virol 1985;16:265-73.

\section{Schoolgirl mothers}

Over 1200 girls under 16 become mothers each year in England and Wales. The incidence has not increased in recent years, but, in contrast, 4000 schoolgirls had abortions in 1983, nearly twice as many as in 1977. Mortality among the children of young mothers is higher than that among those with older mothers, as are rates of prematurity, low birth weight, stunted growth and intellect, and child abuse. ${ }^{12}$ It may be, however, that these adverse outcomes are the result of the general disadvantages of poverty and low social class common to this group rather than specifically of young maternal age. But what are the difficulties for these mothers - parents while still only children themselves?

There are pervasive effects of early motherhood on their physical and mental health, education, economic independence, and social relationships. ${ }^{134} \mathrm{~A}$ recent in depth study of 30 schoolgirls who kept their babies portrayed the experience through the eyes of the girls themselves; most were from broken homes with unemployed parents, and school had held little satisfaction. ${ }^{3}$ Ironically, the luckier mothers found that the special education provided because of their condition had improved their motivation to learn as well as placing them with a peer group, which made them feel less ostracised. They had delayed seeking antenatal care and found attending clinics and classes with older women difficult and sometimes humiliating. When arrangements had been made for group attendance or more individual care attendance had improved. They were very anxious about money.

Most of the girls became pregnant by their first and only partner, who was often no older or more advantaged than they were, and few had plans to marry. They had known about contraceptives but had only a hazy idea about how to obtain them and had unfounded beliefs about the safety of unprotected intercourse. All had moral objections to abortion and adoption. As the researchers concluded, they do not understand the "social reality of under 16 pregnancy and motherhood; do not adequately appreciate the potential results of sexual activity ...; do not realise that biological maturity does not license activating this capacity at will [and] ... that once the baby is born, it takes precedence over its mother ... and at the same time the mother loses her own privileged status as a child.",3

What should be provided for the small but steady numbers of schoolgirl mothers? Many people worry that providing services may imply approval, but not providing services leads to the accumulation of even more disadvantage and contributes to the intergenerational "cycle of deprivation." Intervention programmes should first identify adolescents at risk of precocious pregnancy and provide them with counselling and birth control services. ${ }^{1}$ Next, easy access to termination of unwanted pregnancies should be provided, and, finally, the consequences of pregnancy to mother and child should be minimised by providing medical, social, and educational help, including postnatal contraceptive counselling. One programme showed that return to education was more important in preventing subsequent pregnancy than providing contraceptives. ${ }^{5}$

Special antenatal clinics for pregnant schoolgirls are feasible only in large cities, ${ }^{6}$ but that is where most cases will be found. Should not each university hospital provide one? Should not each education authority ensure that it provides special continuing education for pregnant girls and schoolgirl mothers? Should not the state provide adequate, uniform, and ungrudging financial help? The cost of all thesebecause of the low numbers-would be minuscule. The benefits to these most disadvantaged child parents and their babies would outweigh the costs. ${ }^{3}$

Consultant Child and Adolescent Psychiatrist,

DORA BLACK

Royal Free Hospital,

London NW3 2QG

1 Shaffer D, Pettigrew A, Wolkind S, Zajicek E. Psychiatric aspects of pregnancy in schoolgirls. Psychol Med 1978;8:119-30.

2 Anonymous. School pregnancies [Editorial]. Br Med f 1980;280: 1061-2.

3 Coyne A-M. Schoolgirl mothers. London: Health Education Council, 1986. (Research Report No 2.) 4 Russell JK. Early teenage pregnancy. London: Churchill Livingstone, 1983

5 Klerman LV, Jekel JF. School age mothers: problems, programmes and policy. Connecticut: Shoe String Press, 1973.

6 Osofsky JH, Osofsky JD, Kendall N, Rajan R. Adolescents as mothers: an interdisciplinary approach to a complex problem. Fournal of Youth and Adolescence 1973;2:233-49.

\section{Angioplasty for intermittent claudication}

Percutaneous transluminal angioplasty is now an established treatment for peripheral vascular disease. Under radiological control a balloon catheter is introduced over a guide wire, usually through the femoral artery in the groin. Inflation of the balloon within arterial stenoses or occlusions restores the lumen by cracking the inner diseased layers of the arterial wall and redistributing atheromatous material. ${ }^{12}$ Ideal lesions for treatment are short iliac stenoses and stenoses or short occlusions of the superficial femoral artery. More extensive and more distal lesions can be dealt with successfully, but the chances of the artery staying open are poorer.

As many as two fifths of patients presenting with lower limb arterial disease may be suitable for angioplasty, ${ }^{3}$ and more patients with peripheral arterial disease are now being investigated and treated because of this technique. ${ }^{+5} \mathrm{Com}-$ pared with reconstructive surgery the hospital stay is shorter and the cost for each patient substantially lower. ${ }^{36}$ Angioplasty offers new possibilities for simple treatment of patients with severe and mild disease: unfit patients with severe ischaemia ${ }^{7}$ and a much larger number of patients with intermittent claudication insufficiently severe to justify reconstructive surgery. ${ }^{89}$ Yet if those patients with mild claudication are to be investigated by arteriography with a view to angioplasty the potential benefits and risks must be considered before offering the treatment on a widespread scale.

Selection of patients depends on consultation between vascular surgeons and radiologists. Success rates after two to 